\title{
Short-Term Effects of Sibutramine on Mineral Status and Selected Biochemical Parameters in Obese Women
}

\author{
Joanna Suliburska • Pawel Bogdański • \\ Monika Szulińska • Danuta Pupek-Musialik
}

Received: 10 February 2012 / Accepted: 11 April 2012

(C) The Author(s) 2012. This article is published with open access at Springerlink.com

\begin{abstract}
The aim of this study was to assess the effect of sibutramine on mineral status and selected biochemical parameters in obese women. The study was conducted on 24 patients who received $15 \mathrm{mg}$ daily doses of sibutramine for 12 weeks, and on 20 patients who received placebo. At the baseline, after the sixth and twelfth weeks of treatment, body weight and blood pressure were measured, the BMI was calculated, and samples of blood and of first morning urine were collected. Serum lipid profiles, glucose levels, and nitric oxide levels were determined. The iron (Fe), copper $(\mathrm{Cu})$, zinc $(\mathrm{Zn})$, calcium $(\mathrm{Ca})$, and magnesium $(\mathrm{Mg})$ present in the serum and urine samples were assessed. The erythrocyte hemolysate of the patients was use to assay the activity of glutathione peroxidase (GSH-Px) and superoxide dismutase (SOD). No changes were observed in BMI, blood pressure, or nitric oxide during the study. After 12 weeks of treatment, a decrease was observed in total cholesterol, LDL cholesterol, triglyceride, glucose, and ferritin levels. GSH-Px and SOD activity increased after 12 weeks of sibutramine treatment. The $\mathrm{Mg}$ and $\mathrm{Cu}$ increases was observed in serum after the sixth and twelfth weeks of treatment. It was found that the $\mathrm{Zn}$ level decreased in serum after the twelfth week. The elimination of $\mathrm{Ca}, \mathrm{Mg}$,
\end{abstract}

J. Suliburska $(\bowtie)$

Department of Human Nutrition and Hygiene,

Poznan University of Life Sciences,

Wojska Polskiego 31 Str.,

60-624 Poznan, Poland

e-mail: jsulibur@up.poznan.pl

P. Bogdański • M. Szulińska • D. Pupek-Musialik

Department of Internal Medicine, Metabolic Disorders

and Hypertension, Poznan University of Medical Sciences,

Szamarzewskiego 84 Str.,

60-569 Poznan, Poland
$\mathrm{Fe}, \mathrm{Zn}$, and $\mathrm{Cu}$ in urine also declined in the twelfth week. No differences were found in the women taking the placebo. In conclusion, we found that sibutramine had a positive effect on lipid and glucose status in obese women. However, the drug disturbed the balance of minerals, especially $\mathrm{Zn}$ and $\mathrm{Mg}$, in the subjects.

Keywords Sibutramine $\cdot$ Minerals $\cdot$ Lipid profile $\cdot$ Glucose Obesity · Women

\section{Introduction}

The prevalence of obesity and its comorbidities has been increasing all over the world. Abdominal or visceral obesity is closely related to disturbances in lipid and glucose status, and also to a lower antioxidative status in the body [1]. Weight loss reduces the cardiovascular risks associated with obesity [2]. The treatment of obesity should be individually tailored and should be maintained for a long term. The first line of strategy for weight loss is a combination of diet, physical activity, and behavior modification. Anti-obesity drugs may be used in adult patients when dietary and lifestyle modifications have been unsuccessful.

For a long time, sibutramine was used as an effective anti-obesity drug in Europe, but because of the cardiovascular risk associated with it, European regulators suspended its market authorization, and the US Food and Drug Administration restricted its license. This study was conducted a few months before the withdrawal of sibutramine's license. Over the years, the effectiveness and side effects of sibutramine have been assessed in many studies. Subsequent studies have shown that the drug has a significant effect on weight loss, due to its satietogenic and calorigenic effects [3]. It also improved glycemic and lipid profile and 
uric acid, and for this reason, it was often recommended in diet and lifestyle advice [4]. Svacina et al. [5] documented the positive effect of a 3-month sibutramine treatment on dyslipidemia in the obese, even in those already being treated with statins. In studies with hypertensive subjects whose blood pressure was adequately controlled by antihypertensive drugs, a slight to significant decrease in systolic and diastolic blood pressure was observed with sibutramine use [6]. Moreover, Derosa et al. [7] found that sibutramine plus L-carnitine gave a greater improvement in body weight loss and glycemic and lipid profile compared to sibutramine alone. Sibutramine therapy has been associated with significant $\mathrm{C}$-reactive protein reduction as compared with routine treatment in patients with coronary artery disease. Thus, short-term (4 months) therapy with sibutramine, together with diet and lifestyle modifications, was associated with improved endothelial function [8] but did not affect TNFalpha [9]. In our previous unpublished research, we observed a considerable decrease in ferritin and $\mathrm{Zn}$ concentration in the serum of patient undergoing treatment with sibutramine. A review of the literature on the topic showed that there was limited data on the effects of sibutramine on mineral balance in obese women. The aim of this study was thus to assess the effect of sibutramine on mineral status and on selected biochemical parameters in obese women.

\section{Material and Methods}

\section{Study Design}

The study was conducted at the Department of Internal Diseases, Metabolic Disorders, and Arterial Hypertension, Poznan University of Medical Sciences (Poland), and at the Department of Human Nutrition and Hygiene, Poznan University of Life Sciences (Poland). The study protocol was approved by Bioethics Commission at Poznan University of Medical Sciences (approval no. 86/09).

\section{Patients}

In the Clinic of the Department of Internal Diseases, Metabolic Disorders, and Hypertension in Poznan, we treated obese patients with sibutramine. During the biochemical studies carried out in women taking sibutramine, we observed a considerable decrease in ferritin and $\mathrm{Zn}$ concentration in serum. In addition, these women often complained about the brittleness of their nails and hair and of taste disorders, which may have been due to low concentrations of $\mathrm{Zn}$ in their bodies. This imbalance of mineral status, apparently due to the use of sibutramine, was disturbing, especially when it is known that an appropriate level of minerals, particularly of $\mathrm{Ca}$ and $\mathrm{Fe}$, is very important for the health of women of childbearing age. We thus decided to conduct a study accessing the effect of sibutramine on mineral status in obese women.

The study was conducted on 44 obese women (body mass index $[\mathrm{BMI}] \geq 30 \mathrm{~kg} / \mathrm{m}^{2}$ ) aged $40.6 \pm 12.1$ years. Individuals suffering from chronic disease or using any medications (including OTC products, with the exception of five women who took oral contraceptives) were excluded. For at least 3 months before the study, all women have remained on a controlled-energy diet (with nearly $500 \mathrm{kcal}$ daily deficit) that took $58 \%$ of its calories from carbohydrates, $27 \%$ from fat, and $15 \%$ from proteins, with a maximum cholesterol content of $300 \mathrm{mg} /$ day and $35 \mathrm{~g} /$ day of fiber. Standard dietary advice was given by a qualified dietitian. Subjects did not change their diet during the study and were asked to restrain from smoking for the time of the study.

Women who were pregnant, breastfeeding, or capable of becoming pregnant were excluded. All subjects were informed about the study's purpose, protocol, and risks. All individuals provided informed written consent.

\section{Treatment and Assessment}

Twenty-four patients aged $40.6 \pm 12.1$ were assigned to receive sibutramine $15 \mathrm{mg}$ once daily for 12 weeks, while 20 patients aged $40.7 \pm 12.2$ received placebos containing pure microcrystalline cellulose. Before the beginning of the study, all patients underwent a full physical examination. Anthropometric measurements of the subjects wearing light clothing and no shoes were conducted. Weight was measured to the nearest $0.1 \mathrm{~kg}$, and height to the nearest $0.1 \mathrm{~cm}$. The BMI was calculated by dividing the weight $(\mathrm{kg})$ by the height squared $\left(\mathrm{m}^{2}\right)$. Obesity was defined as $\mathrm{BMI} \geq 30 \mathrm{~kg} / \mathrm{m}^{2}$. Blood pressure was measured according to the guidelines of the European Society of Hypertension using a digital electronic tensiometer (model 705IT, Omron Corporation, Kyoto, Japan). Regular or large adult cuffs were used, depending on the patient's arm circumference. The measurements were taken while fasting in the morning hours in a sitting position, with the legs uncrossed, the back and arms supported. Hypertension was defined by measurement of arterial blood pressure as the average of three measurements obtained after 10 min of physical resting ( 3 times at 2 different visits).

All participants had blood collected from a forearm vein in serum-separated tubes (without using an anticoagulant). The coagulated blood was left to clot at room temperature for $30 \mathrm{~min}$, and then centrifuged for $15 \mathrm{~min}$ at 2,000 rpm at $4^{\circ} \mathrm{C}$. Then the supernatant fluid was separated. Serum samples were stored at $-20^{\circ} \mathrm{C}$ for no longer than 2-3 days. Blood samples were collected after an overnight fast, and after $30 \mathrm{~min}$ in the supine position. 
Measurements of total cholesterol (TC), high density lipoproteins (HDL-C), low density lipoproteins (LDL-C), triglycerides (TG), and glucose were performed on each blood sample. Prior to the $\mathrm{Fe}, \mathrm{Cu}$, and $\mathrm{Zn}$ serum concentration assays, the serum was diluted with triton X-100 (Merck), and before the $\mathrm{Ca}$ and $\mathrm{Mg}$ concentration assays, the serum was diluted with triton and $\mathrm{LaCl}_{3}$ (Merck).

Urine was collected in the morning, following an overnight fast. Morning urine samples were collected in sterilized vessels and stored for material analysis.

The samples of urine were mineralized in a mixture of concentrated nitric $(65 \%)$ and perchloric $(60 \%)$ acids (suprapure, Merck; $v / v, 1: 1)$ in a microwave oven (Milestone), and dissolved ( $v / v, 1: 1)$ in Triton X-100 (Merck; all minerals) and $\mathrm{LaCl}_{3}$ (Merck; $\mathrm{Ca}$ and $\mathrm{Mg}$ ).

After the sixth and twelfth weeks of treatment, weight and blood pressure were measured, BMI was calculated, and the blood samples and first morning urine were collected from all patients. All serum and urine parameters were determined after a 12 -h overnight fast.

\section{Biochemical Assays}

The content of $\mathrm{Fe}, \mathrm{Cu}, \mathrm{Zn}, \mathrm{Ca}$, and $\mathrm{Mg}$ in the serum and urine samples was determined by the flame atomic absorption spectrometry (AAS-3 spectrometer, Carl Zeiss, Germany with deuterium background correction). In order to obtain concentrations of the serum bioelements, the samples were diluted $(v / v, 1: 1)$ as follows: for $\mathrm{Fe}, \mathrm{Zn}$, and $\mathrm{Cu}$ analyses $0.01 \%$ Triton X-100 (Merck) was used, while for the $\mathrm{Mg}$ and $\mathrm{Ca}$ analysis, aqueous solutions consisting of $0.01 \%$ Triton X-100 (Merck) and $0.05 \%$ lanthanum chloride (Merck) were used. The content of $\mathrm{Fe}, \mathrm{Cu}, \mathrm{Zn}, \mathrm{Ca}$, and $\mathrm{Mg}$ in serum and urine samples was determined at the following wavelengths: $248.3 \mathrm{~nm}(\mathrm{Fe}), 324.8 \mathrm{~nm}(\mathrm{Cu})$, $213.9 \mathrm{~nm}(\mathrm{Zn}), 422.7 \mathrm{~nm}(\mathrm{Ca})$, and $285.2 \mathrm{~nm}(\mathrm{Mg})$.

The accuracy of the method was verified using certified reference materials (HUM ASY CONTROL 2 and URN ASY CONTROL 2, Randox), and reached $95 \%$, $99 \%$, $94 \%, 99 \%$, and $102 \%$ for $\mathrm{Ca}, \mathrm{Mg}, \mathrm{Fe}, \mathrm{Zn}$, and $\mathrm{Cu}$, respectively [10].

Plasma TC, LDL-C, HDL-C, TG, and glucose levels were measured using commercial kits. The accuracy and precision of the techniques used to assay the lipids and glucose were validated. Reproducibility was checked with a human serum control (Randox). Accuracy was assessed by means of the recovery value and its range between $95 \%$ and $109 \%$, and the variability coefficient (an indicator of the method's precision) did not exceed $10 \%$.

The activity of glutathione peroxidase (GSH-Px) was assayed in the erythrocyte hemolysate using a method of Paglia and Valentine [11]. GSH-Px decomposes hydrogen peroxide, causing oxidation of the reduced glutathione. Oxidized glutathione is then reduced in a reaction that is catalyzed by glutathione reductase. The coenzyme of the reaction is reduced nicotinamide adenine dinucleotide phosphate, which is transformed into oxidized form, and causes a change in light absorbance at $340 \mathrm{~nm}$ (spectrophotometer Sunrise, Tecan). Superoxide dismutase (SOD) activity was determined in the erythrocyte hemolysate using a modification of epinephrine-adenochrome detection system [12]. The enzyme inhibits the reaction of adrenaline autooxidation to adenochrome in an alkaline environment. The unit of SOD activity under the given conditions is defined as the amount of enzyme that inhibits $50 \%$ of the reaction at the maximal increase of absorbance rectilinear segment of adenochrome formation at wavelength $450 \mathrm{~nm}$ (spectrophotometer Sunrise, Tecan). Erythrocyte GSH-Px and SOD activity was determined using a commercial kit (Randox), and expressed as units per gram of hemoglobin. The hemoglobin concentration in milligrams per milliliters was determined using the cyanmethemoglobin method [13].

Erythrocyte lysate was prepared from blood collected with EDTA. Blood was centrifuged at $700-1,000 \times g$ at $4^{\circ} \mathrm{C}$. Plasma was then removed. The red cells were washed three times with cold isotonic saline solution. Erythrocytes were lysed with a ninefold volume of ice-cold HPLC-grade water, and then centrifuged at $10,000 \times g$ at $4^{\circ} \mathrm{C}$. Supernatant was used for assaying.

The concentration of ferritin in the serum was determined by a two-site sandwich immunoassay using direct chemiluminometric technology (ADVIA Centaur XP analyzer), which uses constant amounts of two anti-ferritin antibodies [14].

The concentration of nitric oxide (NO) was determined using the spectrophotometric method on the serum, with the testing set by Oxis. The test determines nitric oxide concentration based on the enzymatic conversion of nitrate to nitrite by nitrate reductase. The reaction is followed by colorimetric detection of nitrate as an azo dye product of the Griess Reaction. The Griess reaction transforms nitrites to NO, which then reacts with sulfanilic acid, and the indirect product of the reaction interacts with $\mathrm{N}-(1$-naphtyl) ethylendiamine, leading to the formation of a red-violet colored product having maximum absorbance at $\lambda=$ $540 \mathrm{~nm}$. The solution color change, measured spectrophotometrically (with Hyperion Micro Reader), is proportional to the nitric oxide concentration [15].

\section{Statistical Analysis}

The experimental results were given as means \pm standard deviation. The statistical analysis was carried out using STATISTICA 7.0 software and the ANOVA test. A $p$ value less than 0.05 was considered statistically significant. 


\section{Results}

Body Mass Index and Blood Pressure

The results of BMI and blood pressure measurements are presented in Table 1. No significant change was observed in BMI or in the systolic or diastolic blood pressure of patients during the study. However, the body mass index slightly decreased after 6 weeks (38.43 vs. 37.93, $p=0.345)$ and 12 weeks ( 38.43 vs. $36.83, p=0.204)$. Both systolic and diastolic blood pressure did not change at all in comparison with the baseline.

\section{Biochemical Parameters}

After 6 weeks of sibutramine treatment, a significant decrease was found only in TC ( $p=0.031$; Table 2$)$. No change in LDL-C, TG, glucose, or ferritin levels was observed at 6 weeks. After 12 weeks, a significant decrease was observed for TC $(p=0.013)$, LDL-C $(p=0.034)$, TG $(p=$ $0.044)$, glucose $(p=0.046)$, and ferritin $(p=0.030)$. GSHPX and SOD activity markedly increased $(p=0.036$ and $p=0.021$, respectively) after 12 weeks of sibutramine treatment. Serum levels of NO did not change during the study. In women taking the placebo, no significant difference was observed.

Minerals

A significant increase in $\mathrm{Mg}$ and $\mathrm{Cu}$ concentration was observed in the serum of women with sibutramine after 6 ( $p=0.037$ and $p=0.029$, respectively) and 12 weeks ( $p=$ 0.030 and $p=0.021$, respectively; Table 3 ). It was also found that $\mathrm{Zn}$ levels markedly decreased $(p=0.018)$ in serum after 12 weeks, and a slight decrease was also observed after
6 weeks of treatment. In the case of Fe serum concentration, a slight decrease was found during the study.

The elimination of $\mathrm{Ca}, \mathrm{Mg}, \mathrm{Fe}$, and $\mathrm{Cu}$ in urine declined significantly at 6 weeks $(p=0.032, p=0.048, p=0.037$, and $p=0.026$, respectively) and 12 weeks $(p=0.028, p=0.031$, $p=0.023$, and $p=0.018$, respectively) of the study (Table 3 ). The considerable decrease in $\mathrm{Zn}$ concentration in urine was observed only after 12 weeks $(p=0.017)$, but a slight decline in $\mathrm{Zn}$ elimination was evident after 6 weeks of the study.

It was found that the $\mathrm{Ca} / \mathrm{Mg}$ and $\mathrm{Zn} / \mathrm{Cu}$ molar ratios in serum significantly decreased at the sixth $(p=0.042$ and $p=$ $0.032)$ and twelfth weeks $(p=0.034$ and $p=0.021)$ of the study (Table 4 ). A marked $\mathrm{Cu} / \mathrm{Fe}$ molar ratio increase was present at $6(p=0.035)$ and 12 weeks $(p=0.028)$ vs. the baseline, and at 12 weeks vs. 6 weeks $(p=0.046)$. In urine, significant increases in the molar ratios of $\mathrm{Ca} / \mathrm{Mg}$ and $\mathrm{Zn} /$ $\mathrm{Cu}$, as well as a significant decrease in the $\mathrm{Fe} / \mathrm{Zn}$ molar ratio at 6 ( $p=0.016, p=0.027$, and $p=0.041$, respectively) and 12 weeks ( $p=0.013, p=0.022$, and $p=0.037$, respectively) of sibutramine treatment were observed. No marked differences in women receiving the placebo were found.

\section{Discussion}

Sibutramine hydrochloride monohydrate is a norepinephrine and serotonin reuptake inhibitor approved for the long-term management of obesity, in conjunction with a reduced calorie diet and behavior modification in patients unable to lose weight by means of diet and lifestyle changes alone. The efficacy of sibutramine has been demonstrated in randomized trials in obese patients [16-18]. Furthermore, its favorable influence on the lipid profile and glucose concentration has been shown in several studies [19-21]. In the study of Tambascia et al. [22], sibutramine demonstrated efficacy in

Table 1 Baseline values

\begin{tabular}{|c|c|c|c|c|c|c|}
\hline & \multicolumn{2}{|l|}{ Baseline } & \multicolumn{2}{|l|}{6 weeks } & \multicolumn{2}{|l|}{12 weeks } \\
\hline & $\begin{array}{l}\text { Sibutramine } \\
(N=24)\end{array}$ & $\begin{array}{l}\text { Placebo } \\
(N=20)\end{array}$ & $\begin{array}{l}\text { Sibutramine } \\
(N=24)\end{array}$ & $\begin{array}{l}\text { Placebo } \\
(N=20)\end{array}$ & $\begin{array}{l}\text { Sibutramine } \\
(N=24)\end{array}$ & $\begin{array}{l}\text { Placebo } \\
(N=20)\end{array}$ \\
\hline $\mathrm{N}$ & 24 & 20 & - & - & - & - \\
\hline $\operatorname{Sex}[\mathrm{F}]$ & 24 & 20 & - & - & - & - \\
\hline Age [years] & $40.61 \pm 12.13$ & $40.72 \pm 12.22$ & - & - & - & - \\
\hline Sibutramine [dose] & $15 \mathrm{mg}$ & - & $15 \mathrm{mg}$ & - & $15 \mathrm{mg}$ & - \\
\hline BMI $\left[\mathrm{kg} / \mathrm{m}^{2}\right]$ & $38.43 \pm 8.54$ & $38.03 \pm 5.76$ & $37.93 \pm 7.54$ & $37.55 \pm 6.21$ & $36.83 \pm 7.35$ & $37.31 \pm 4.83$ \\
\hline $\mathrm{SBP}[\mathrm{mmHg}]$ & $133.52 \pm 10.44$ & $131.82 \pm 8.37$ & $133.18 \pm 12.42$ & $132.87 \pm 8.91$ & $133.57 \pm 9.74$ & $132.38 \pm 8.31$ \\
\hline $\mathrm{DBP}[\mathrm{mmHg}]$ & $85.53 \pm 5.22$ & $85.77 \pm 5.42$ & $85.68 \pm 5.61$ & $85.73 \pm 5.34$ & $85.42 \pm 4.81$ & $85.74 \pm 4.11$ \\
\hline
\end{tabular}

Blood pressure and BMI changes at 6 and 12 weeks in the group during the study. Data are means \pm SD

mean the arithmetic mean, $S D$ standard deviation, $N$ number of subjects, $B M I$ body mass index, $S B P$ systolic blood pressure, $D B P$ diastolic blood pressure 
Table 2 Biochemical parameters in serum changes at 6 and 12 weeks during the study

\begin{tabular}{|c|c|c|c|c|c|c|}
\hline & \multicolumn{2}{|l|}{ Baseline } & \multicolumn{2}{|l|}{6 weeks } & \multicolumn{2}{|l|}{12 weeks } \\
\hline & $\begin{array}{l}\text { Sibutramine } \\
(N=24)\end{array}$ & $\begin{array}{l}\text { Placebo } \\
(N=20)\end{array}$ & $\begin{array}{l}\text { Sibutramine } \\
(N=24)\end{array}$ & $\begin{array}{l}\text { Placebo } \\
(N=20)\end{array}$ & $\begin{array}{l}\text { Sibutramine } \\
(N=24)\end{array}$ & $\begin{array}{l}\text { Placebo } \\
(N=20)\end{array}$ \\
\hline $\mathrm{TC}[\mathrm{mmol} / \mathrm{l}]$ & $4.41 \pm 0.58$ & $4.40 \pm 0.51$ & $4.11 \pm 0.57^{\mathrm{a}}$ & $4.38 \pm 0.56$ & $4.08 \pm 0.58^{\mathrm{a}}$ & $4.35 \pm 0.52$ \\
\hline LDL-C $[\mathrm{mmol} / 1]$ & $2.56 \pm 0.48$ & $2.55 \pm 0.51$ & $2.35 \pm 0.46$ & $2.52 \pm 0.49$ & $2.28 \pm 0.42^{\mathrm{a}}$ & $2.50 \pm 0.43$ \\
\hline HDL-C [mmol/l] & $1.25 \pm 0.24$ & $1.28 \pm 0.21$ & $1.26 \pm 0.25$ & $1.28 \pm 0.23$ & $1.25 \pm 0.26$ & $1.26 \pm 0.21$ \\
\hline $\mathrm{TG}[\mathrm{mmol} / \mathrm{l}]$ & $1.37 \pm 0.37$ & $1.35 \pm 0.38$ & $1.21 \pm 0.36$ & $1.30 \pm 0.30$ & $1.15 \pm 0.35^{\mathrm{a}}$ & $1.30 \pm 0.31$ \\
\hline Glucose $[\mathrm{mmol} / \mathrm{l}]$ & $5.35 \pm 0.47$ & $5.31 \pm 0.48$ & $5.33 \pm 0.46$ & $5.30 \pm 0.47$ & $5.18 \pm 0.27^{\mathrm{a}}$ & $5.30 \pm 0.50$ \\
\hline Ferritin $[\mu \mathrm{g} / 1]$ & $91.12 \pm 40.42$ & $91.25 \pm 41.22$ & $78.15 \pm 41.39$ & $88.11 \pm 40.08$ & $65.51 \pm 38.50^{\mathrm{a}}$ & $85.14 \pm 30.83$ \\
\hline Nitric oxide $(\mathrm{NO})[\mu \mathrm{mol} / 1]$ & $10.60 \pm 3.01$ & $10.67 \pm 2.67$ & $10.83 \pm 3.08$ & $10.57 \pm 2.68$ & $10.67 \pm 2.99$ & $10.60 \pm 2.68$ \\
\hline Glutathione peroxidase $[\mathrm{U} / \mathrm{gHb}]$ & $15.62 \pm 6.30$ & $15.68 \pm 7.11$ & $18.26 \pm 8.23$ & $16.15 \pm 7.83$ & $19.52 \pm 8.45^{\mathrm{a}}$ & $16.22 \pm 6.28$ \\
\hline Superoxide dismutase [U/gHb] & $2,570 \pm 692$ & $2,582 \pm 5.82$ & $2,853 \pm 576$ & $2,637 \pm 583$ & $3,554 \pm 723^{\mathrm{a}}$ & $2,628 \pm 683$ \\
\hline
\end{tabular}

Data are means \pm SD

mean the arithmetic mean, $S D$ standard deviation, $N$ number of subjects, $T C$ total cholesterol, $L D L-C$ LDL cholesterol, $H D L-C$ HDL cholesterol, $T G$ triglycerides

${ }^{a}$ Sibutramine group $p<0.05$ vs baseline

reducing weight, insulin resistance, triglicerides, and uric acid, but not glucose or cholesterol, in non-diabetic women. The results of our study after 6 weeks show a significant decrease only for TC. No change in LDL-C, TG, glucose levels were observed at that time. After 12 weeks, a significant decrease in TC, LDL-C, TG, and glucose was observed.

Some authors suggest that the use of sibutramine could raise blood pressure on account of its peripheral sympathomimetic effect [23]. Contrarily, reports of other authors and the results of our own study show no significant impact of sibutramine on blood pressure or on NO concentration in long-term or short-term treatment $[3,24]$. It is suggested that sibutramine elicits a central sympatholytic effect in the brain, counteracting, at least in part, peripheral sympathetic stimulation.

To the best of our knowledge, this is the first clinical study investigating the effect of sibutramine on mineral status in obese women. The results of the experimental studies suggest the potential influence of sibutramine on minerals. Emer et al. [25] found that a relatively high dose of sibutramine resulted in significant increases in $\mathrm{Fe}$ and $\mathrm{Zn}$ levels in the kidneys and in the adrenal glands in rats. The results of our study show significant changes in mineral levels of obese women treated with sibutramine.

The mechanism may be related to reduced energy intake as an effect of sibutramine action. It has been demonstrated that lower food intake leads to a lower supply of minerals
Table 3 Minerals in serum and urine changes at 6 and 12 weeks during the study

Data are means \pm SD

mean the arithmetic mean, $S D$ standard deviation, $N$ number of subjects

${ }^{\text {a }}$ Sibutramine group $p<0.05$ vs baseline

\begin{tabular}{|c|c|c|c|c|c|c|}
\hline & \multicolumn{2}{|l|}{ Baseline } & \multicolumn{2}{|l|}{6 weeks } & \multicolumn{2}{|l|}{12 weeks } \\
\hline & $\begin{array}{l}\text { Sibutramine } \\
(N=24)\end{array}$ & $\begin{array}{l}\text { Placebo } \\
(N=20)\end{array}$ & $\begin{array}{l}\text { Sibutramine } \\
(N=24)\end{array}$ & $\begin{array}{l}\text { Placebo } \\
(N=20)\end{array}$ & $\begin{array}{l}\text { Sibutramine } \\
(N=24)\end{array}$ & $\begin{array}{l}\text { Placebo } \\
(N=20)\end{array}$ \\
\hline \multicolumn{7}{|l|}{ Serum } \\
\hline $\mathrm{Ca}$ [mmol]1] & $2.54 \pm 0.13$ & $2.52 \pm 0.12$ & $2.65 \pm 0.42$ & $2.60 \pm 0.21$ & $2.52 \pm 0.25$ & $2.50 \pm 0.33$ \\
\hline $\mathrm{Mg}[\mathrm{mmol} / \mathrm{l}]$ & $0.80 \pm 0.07$ & $0.83 \pm 0.07$ & $0.93 \pm 0.06^{\mathrm{a}}$ & $0.85 \pm 0.06$ & $0.95 \pm 0.06^{\mathrm{a}}$ & $0.88 \pm 0.25$ \\
\hline $\mathrm{Fe}[\mu \mathrm{mol} / 1]$ & $17.85 \pm 5.32$ & $17.33 \pm 5.18$ & $16.82 \pm 6.24$ & $16.84 \pm 5.10$ & $16.35 \pm 5.92$ & $16.58 \pm 5.03$ \\
\hline $\mathrm{Zn}[\mu \mathrm{mol} / 1]$ & $12.42 \pm 2.42$ & $12.04 \pm 2.80$ & $11.48 \pm 2.38$ & $11.96 \pm 2.81$ & $10.51 \pm 2.58^{\mathrm{a}}$ & $11.46 \pm 2.91$ \\
\hline $\mathrm{Cu}[\mu \mathrm{mol} / 1]$ & $13.61 \pm 1.81$ & $13.03 \pm 1.71$ & $14.94 \pm 1.78^{\mathrm{a}}$ & $13.41 \pm 1.80$ & $15.68 \pm 1.92^{\mathrm{a}}$ & $13.63 \pm 1.21$ \\
\hline \multicolumn{7}{|l|}{ Urine } \\
\hline $\mathrm{Ca}[\mathrm{mmol} / \mathrm{l}]$ & $3.84 \pm 2.53$ & $3.21 \pm 2.31$ & $2.97 \pm 2.09^{\mathrm{a}}$ & $3.25 \pm 2.30$ & $2.89 \pm 2.35^{\mathrm{a}}$ & $3.18 \pm 2.18$ \\
\hline $\mathrm{Mg}[\mathrm{mmol} / \mathrm{l}]$ & $5.84 \pm 2.42$ & $5.50 \pm 2.80$ & $3.25 \pm 1.78^{\mathrm{a}}$ & $5.00 \pm 1.80$ & $3.05 \pm 1.50^{\mathrm{a}}$ & $4.58 \pm 2.91$ \\
\hline $\mathrm{Fe}[\mu \mathrm{mol} / 1]$ & $9.27 \pm 5.21$ & $9.30 \pm 4.77$ & $6.02 \pm 4.20^{\mathrm{a}}$ & $8.50 \pm 4.18$ & $5.78 \pm 3.84^{\mathrm{a}}$ & $7.90 \pm 5.10$ \\
\hline $\mathrm{Zn}[\mu \mathrm{mol} / 1]$ & $9.38 \pm 3.58$ & $9.40 \pm 3.37$ & $8.46 \pm 4.21$ & $8.98 \pm 4.80$ & $7.78 \pm 3.80^{\mathrm{a}}$ & $9.12 \pm 2.83$ \\
\hline $\mathrm{Cu}[\mu \mathrm{mol} / 1]$ & $1.02 \pm 0.51$ & $1.11 \pm 0.68$ & $0.68 \pm 0.34^{\mathrm{a}}$ & $0.98 \pm 0.80$ & $0.61 \pm 0.35^{\mathrm{a}}$ & $1.08 \pm 0.56$ \\
\hline
\end{tabular}


Table 4 Mineral molar ratio in serum and urine changes at 6 and 12 weeks during the study
Data are means \pm SD

mean the arithmetic mean, $S D$ standard deviation, $N$ number of subjects

${ }^{\mathrm{a}}$ Sibutramine group $p<0.05$ vs baseline

${ }^{\mathrm{b}}$ Sibutramine group $p<0.05$ vs 6 weeks

\begin{tabular}{|c|c|c|c|c|c|c|}
\hline & \multicolumn{2}{|l|}{ Baseline } & \multicolumn{2}{|l|}{6 weeks } & \multicolumn{2}{|l|}{12 weeks } \\
\hline & $\begin{array}{l}\text { Sibutramine } \\
(N=24)\end{array}$ & $\begin{array}{l}\text { Placebo } \\
(N=20)\end{array}$ & $\begin{array}{l}\text { Sibutramine } \\
(N=24)\end{array}$ & $\begin{array}{l}\text { Placebo } \\
(N=20)\end{array}$ & $\begin{array}{l}\text { Sibutramine } \\
(N=24)\end{array}$ & $\begin{array}{l}\text { Placebo } \\
(N=20)\end{array}$ \\
\hline \multicolumn{7}{|l|}{ Serum } \\
\hline $\mathrm{Ca} / \mathrm{Mg}$ & $3.16 \pm 0.21$ & $3.04 \pm 0.20$ & $2.85 \pm 0.27^{\mathrm{a}}$ & $3.06 \pm 0.25$ & $2.66 \pm 0.23^{\mathrm{a}}$ & $2.84 \pm 0.20$ \\
\hline $\mathrm{Fe} / \mathrm{Zn}$ & $1.44 \pm 0.12$ & $1.440 \pm .13$ & $1.47 \pm 0.12$ & $1.41 \pm 0.14$ & $1.56 \pm 0.12$ & $1.45 \pm 0.10$ \\
\hline $\mathrm{Cu} / \mathrm{Fe}$ & $0.76 \pm 0.09$ & $0.75 \pm 0.10$ & $0.89 \pm 0.05^{\mathrm{a}}$ & $0.80 \pm 0.04$ & $0.96 \pm 0.05^{\mathrm{a}, \mathrm{b}}$ & $0.82 \pm 0.07$ \\
\hline $\mathrm{Zn} / \mathrm{Cu}$ & $0.92 \pm 0.11$ & $0.92 \pm 0.12$ & $0.77 \pm 0.12^{\mathrm{a}}$ & $0.89 \pm 0.18$ & $0.66 \pm 0.12^{\mathrm{a}}$ & $0.86 \pm 0.09$ \\
\hline \multicolumn{7}{|l|}{ Urine } \\
\hline $\mathrm{Ca} / \mathrm{Mg}$ & $0.65 \pm 0.23$ & $0.59 \pm 0.25$ & $0.92 \pm 0.21^{\mathrm{a}}$ & $0.65 \pm 0.25$ & $0.95 \pm 0.21^{\mathrm{a}}$ & $0.69 \pm 0.31$ \\
\hline $\mathrm{Fe} / \mathrm{Zn}$ & $0.98 \pm 0.31 \mathrm{a}$ & $0.98 \pm 0.30$ & $0.72 \pm 0.30^{\mathrm{a}}$ & $0.95 \pm 0.31$ & $0.74 \pm 0.31^{\mathrm{a}}$ & $0.87 \pm 0.40$ \\
\hline $\mathrm{Cu} / \mathrm{Fe}$ & $0.11 \pm 0.05$ & $0.12 \pm 0.06$ & $0.11 \pm 0.04$ & $0.12 \pm 0.06$ & $0.11 \pm 0.04$ & $0.13 \pm 0.07$ \\
\hline $\mathrm{Zn} / \mathrm{Cu}$ & $9.20 \pm 3.78 \mathrm{a}$ & $8.47 \pm 3.05$ & $12.5 \pm 4.65^{\mathrm{a}}$ & $9.16 \pm 5.08$ & $12.8 \pm 5.33^{\mathrm{a}}$ & $8.45 \pm 3.08$ \\
\hline
\end{tabular}

and reduced mineral status in the body. Acuirre et al. [26] reported that a 1,000 kcal/day diet decreases the intake of $\mathrm{Fe}, \mathrm{Zn}, \mathrm{Cu}$, and $\mathrm{Ca}$ by $50 \%, 30 \%, 40 \%$, and $9 \%$, respectively.

This weight-reducing diet led to a reduction of Fe status in obese patients, as indicated by the decrease in serum ferritin. In our study, a significant decrease in ferritin, with a slight (but not significant) reduction in body mass, was also observed, though only in the women taking sibutramine, and not in the group administered the placebo.

However, in the present study, the decreased level of ferritin is connected with increased GSH-Px and SOD level in the blood, which suggests that the change in serum ferritin level is also associated with a change in inflammation in the body of obese women during the sibutramine treatment. Our results may be consistent with the observation of Zafon et al. [27], who claim that ferritin concentration in the obese is due to inflammation, rather than to the $\mathrm{Fe}$ status of the body.

The excretion of minerals in the urine of the studied subjects may be a reflection of a change in the mineral status of the body. Changes in the excretion of minerals are not uniform, as shown in Table 3. This is evidenced by the change in molar ratios of elements in the excreted urine. The molar ratios of minerals in the blood also changed. In each tissue of the body, the ion balance is maintained and remains constant. The evaluation of mineral status and mineral metabolism in the body is possible on the basis of the proportions found to hold between different minerals. There are synergistic and antagonistic relationships between the minerals, which directly affect the metabolism of the body. Keeping an appropriate balance between the elements is, in many cases, more important than their normal levels in the tissue. Changes in the ratio between minerals in tissues indicate metabolic disorders in the body and/or interactions between minerals. In the present study, following the sibutramine treatment we observed a decrease in the $\mathrm{Ca}$ level (though insignificant) and a higher concentration of $\mathrm{Mg}$ in serum. $\mathrm{Ca}$ and $\mathrm{Mg}$ levels in the body are regulated by a negative-feedback system, and through competition for intestinal absorption and renal reabsorption. $\mathrm{Ca}$ and $\mathrm{Mg}$ also compete for membrane binding sites within the cell. A lower $\mathrm{Ca} / \mathrm{Mg}$ ratio in the serum, and higher $\mathrm{Ca} / \mathrm{Mg}$ ration in urine is probably the result of the disturbed $\mathrm{Mg}$ status following sibutramine treatment.

Slightly lower $\mathrm{Fe}$ and $\mathrm{Zn}$ levels, as well as higher $\mathrm{Cu}$ concentrations, were found in the serum after 6 and 12 weeks of the study vs. the baseline. These changes may indicate interactions between the elements due to the use of sibutramine. Known interactions of $\mathrm{Ca}-\mathrm{Mg}$ and $\mathrm{Fe}-\mathrm{Zn}-\mathrm{Cu}$ can be observed. The higher $\mathrm{Cu} / \mathrm{Fe}$ ratio and lower $\mathrm{Zn} / \mathrm{Cu}$ ratio in the serum of patients after treatment may be affected by a disturbed Zn status. Decreasing the $\mathrm{Zn}$ level in the organism increases the $\mathrm{Cu}$ level, which is a result of the $\mathrm{Zn}-\mathrm{Cu}$ antagonism.

In other studies, low plasma Zn levels were observed in obese [28], and obese type-2 diabetic individuals [29]. Similarly, rather low plasma Zn level was observed in obese women in the current study. In some studies based on hypocaloric diets and physical activity, weight loss in obese women was associated with increased plasma $\mathrm{Zn}$, and this increase was not a reflection of diet [28]. In this study, we observed an inverse relationship. Moreover, Konukoglua et al. [29] found negative correlations between leptin and $\mathrm{Zn}$ in serum among obese diabetic subjects. The results obtained in our study may indicate the effects of sibutramine, but not of weight loss or leptin concentration decrease (not analyzed in this study), on changes in the $\mathrm{Zn}$ concentration in the serum of obese women. It has been shown that $\mathrm{Zn}$ may contribute to the modulation of serotonin uptake in the brain [30]. Sibutramine is a serotonin uptake inhibitor, and so sibutramine by influencing serotonin metabolism might also 
indirectly disturb the $\mathrm{Zn}$ status of the body. The influence of sibutramine on neurotransmitters may also indirectly affect the level of $\mathrm{Cu}$ in the body. It has been found that $\mathrm{Cu}$ metabolism is associated with neurological functions (and with the level of serotonin in the brain) [31, 32]. Moreover, Lima et al. did not report any differences in $\mathrm{Cu}$ concentration in serum or erythrocytes when comparing obese and non-obese female children [33]. In the present study we observed that, along with the decrease in the concentration of TG and TC, the levels of $\mathrm{Fe}$ and $\mathrm{Zn}$ lowered significantly, while level of $\mathrm{Cu}$ in the serum increased. The results are consistent with the data from our previous study, where obese patients with hypertension and insulin resistance were studied [34].

Treatment with sibutramine resulted in increase in GSHPx and SOD activity in the serum. GSH-Px is the main enzyme of the enzymatic antioxidant defense system responsible for protecting against increases in ROS production [35]. Hydrogen peroxide, formed by the catalytic reaction of SOD, is both a reactive form of oxygen and a normal cellular metabolite, and it is further detoxified by GSH-Px and catalase [36]. The erythrocyte is a relatively abundant focus of both free-radical-mediated injury by virtue of enhanced endogenous rates of production of ROS and impairment of tissue-free radical defense mechanisms [37, 38]. In addition, GSH is the substrate of GSH-Px, and the cysteine derivative GSH is synthesized in erythrocytes, and glutathione disulfide transported outside the cell to maintain a high GSH/GSSG ratio [35, 38]. Disulfide-exchange reactions occur between protein thiols and low molecular weight disulfides [36]. In our present study, GSH-Px and SOD activities in erythrocytes increased in the treatment groups after the twelfth week. The observed changes may result from an alternation of mineral concentrations during sibutramine treatment. This possible relation was reported by Vivoli et al., who found a positive relationship between serum $\mathrm{Cu}$ and $\mathrm{Cu}-\mathrm{Zn}$ SOD [39]. Moreover PiorunskaStoltzman et al. [40] reported a positive correlation between $\mathrm{Cu}$ and GSH-Px in serum. The increase of erythrocyte GSH-Px and SOD values in patients during sibutramine treatments has also been attributed to the inhibition of free oxygen radicals and lipid peroxidation [41], and the protective effects of sibutramine supplementation on glucose-6phosphate dehydrogenase activity in erythrocytes.

Our study has some limitations, for example short treatment and the relatively small group of subjects. These limitations result from group selection procedure, requiring women without chronic diseases and not using additional drugs. Moreover, this study was interrupted by the withdrawal of sibutramine license in the EU. Finally, based on these results and the literature data, it is difficult to explain the precise mechanism of the mineral changes in the serum and urine during sibutamine treatment. A better understanding of this mechanism requires further extensive biochemical studies.

\section{Conclusion}

Sibutramine favorably influences the lipid profile and glucose concentration in obese women. Additionally, treatment with sibutramine is associated with increase in GSH-Px and SOD activity. However, 12-week sibutramine therapy decreases $\mathrm{Zn}$ and increases $\mathrm{Mg}$ concentrations in the serum, leading to mineral imbalances in obese women. The control of minerals levels, particularly of $\mathrm{Zn}$, and the potential need for further supplementation should be considered in patients treated with sibutramine.

Open Access This article is distributed under the terms of the Creative Commons Attribution License which permits any use, distribution, and reproduction in any medium, provided the original author(s) and the source are credited.

\section{References}

1. Logue J, Murray HM, Welsh P, Shepherd J, Packard Ch, Macfarlane P, Cobbe S, Ford I, Sattar N (2011) Obesity is associated with fatal coronary heart disease independently of traditional risk factors and deprivation. Heart 97(7):564-568

2. Goodpaster BH, DeLany JP, Otto AD, Kuller L, Vockley J, South-Paul JE, Thomas SB, Brown J, McTique K, Hames KC, Lang W, Jakicic JM (2010) Effects of diet and physical activity interventions on weight loss and cardiometabolic risk factors in severely obese adults: a randomized trial. JAMA 304 (16): $1795-1802$

3. de Lemos H, Atallah AN, de Lemos ALA (2008) Can sibutramine alter systemic blood pressure in obese patients? Systematic review and meta-analysis. Sao Paulo Med J 126(6):342-346

4. Smith IG, Goulder MA (2001) Sibutramine Clinical Study 1047 Team. Randomized placebo-controlled trial of long-term treatment with sibutramine in mild to moderate obesity. J Fam Pract 50(6):505512

5. Svacina S, Owen K, Hendl J, Matoulek M, Brychta T (2007) Lipid lowering effect of sibutramine in statin treated patients comparison of lipid lowering effect of sibutramine in patients treated or not treated with statins - 3 month follow-up. Prague Med Rep 108 (4):333-338

6. Derosa G, Cicero AF, Murdolo G, Piccinni MN, Fogari E, Bertone G, Ciccarelli L, Fogari R (2005) Efficacy and safety comparative evaluation of orlistat and sibutramine treatment in hypertensive obese patients. Diabetes Obes Metab 7(1):47-55

7. Derosa G, Maffioli P, Salvadeo SA, Ferrari I, Gravina A, Mereu R, D'Angelo A, Palumbo I, Randazzo S, Cicero AF (2010) Sibutramine and L-carnitine compared to sibutramine alone on insulin resistance in diabetic patients. Intern Med 49(16):1717-1725

8. Shechter M, Beigel R, Freimark D, Matetzky S, Feinberg MS (2006) Short-term sibutramine therapy is associated with weight loss and improved endothelial function in obese patients with coronary artery disease. Am J Cardiol 97:1650-1653 
9. Trapali M, Liapi C, Perelas A, Perrea D, Stroubini T, Dontas I, Couvari E, Mavri M, Galanopoulou P (2008) Effect of isocaloric diets and sibutramine on food intake, body mass variation and serum TNF-alpha levels in rats. Pharmacology 82(1):15-21

10. Dastych M, Prochazkova D, Pokorny A, Zdrazil L (2010) Copper and zinc in the serum, urine and hair of patients with Wilson's disease treated with penicillamine and zinc. Biol Trace Elem Res 133:265-269

11. Paglia DE, Valentine WN (1967) Studies on the quantitative and qualitative characterization of erythrocyte glutathione peroxidase. $\mathrm{J}$ Lab Clin Med 70:158-169

12. Misra HP, Fridovich I (1972) The role of superoxide anion in the autooxidation of epinephrine and a simple assay for superoxide dismutase. J Biol Chem 247:3170-3175

13. Mahoney JJ, Vreman HJ, Stevenson DK, Van Kessel AL (1993) Measurement of carboxyhemoglobin and total hemoglobin by five specialized spectrophotometers (Co-oximeters) in comparison with reference methods. Clin Chem 39:1693-1700

14. National Committee for Clinical Laboratory Standards (NCCLS) (1996) Clinical Laboratory Procedure Manuals Third Edition (GP2-A3)

15. Miles AM, Wink DA, Cook JC, Grisham WB (1996) Determination of nitric oxide using fluorescence spectroscopy. Methods Enzymol 268:105-120

16. James WP, Astrup A, Finer N, Hilsted J, Kopelman P, Rössner S, Saris WH, Van Gaal LF (2000) Effect of sibutramine on weight maintenance after weight loss: a randomised trial. STORM Study Group. Sibutramine Trial of Obesity Reduction and Maintenance. Lancet 356:2119-2125

17. Wadden TA, Berkowitz RI, Womble LG, Sarwer DB, Phelan S, Cato RK, Hesson LA, Osei SY, Kaplan R, Stunkard AJ (2005) Randomized trial of lifestyle modification and pharmacotherapy for obesity. N Engl J Med 353:2111-2120

18. Finer N, Bloom SR, Frost GS, Banks LM, Griffiths J (2000) Sibutramine is effective for weight loss and diabetic control in obesity with type 2 diabetes: a randomised, double-blind, placebocontrolled study. Diabetes Obes Metab 2:105-112

19. McMahon FG, Fujioka K, Bramah N, Mendel CM, Rowe E, Rolston K, Johnson F, Mooradian AD (2000) Efficacy and safety of sibutramine in obese white and African American patients with hypertension a 1-year, double-blind, placebo-controlled, multicenter trial. Arch Intern Med 160:2185-2191

20. Derosa G, Maffioli P, Ferrari I, Palumbo I, Randazzo S, D’Angelo A, Cicero AF (2010) Effects of one year treatment of sibutramine on insulin resistance parameters in type 2 diabetic patients. J Pharm Pharm Sci 13(3):378-390

21. Weeke P, Andersson Ch, Fosbol EL, Brendorp B, Kober L, Sharma AM, Finer N, James P, Caterson ID, Rode RA, Torp-Pedersen Ch (2010) The weight lowering effect of sibutramine and its impact on serum lipids in cardiovascular high risk patients with and without type 2 diabetes mellitus - an analysis from the SCOUT lead-in period. BMC Endocr Disord 10 (3): $1-9$

22. Tambascia MA, Geloneze B, Repetto EM, Geloneze SR, Picolo M, Magro DO (2003) Sibutramine enhances insulin sensitivity ameliorating metabolic parameters in a doubleblind, randomized, placebo-controlled trial. Diabetes Obes Metab 5:338-344

23. Doggrell SA (2005) Clinical evidence for drug treatments in obesity-associated hypertensive patients - a discussion paper. Methods Find Exp Clin Pharmacol 27(2):119-125

24. Gursoy A, Erdogan MF, Cin MO, Cesur M, Baskal N (2005) Effect of sibutramine on blood pressure in patients with obesity and well-controlled hypertension or normotension. Endocr Pract 11 (5):308-312
25. Emer E, Kaplan B, Kaya S, Aliyev V, Arica E, Soylemezoglu T (2010) Effect of high dose sibutramine application on serum serotonin, plasma noradrenaline and on zinc and iron levels in liver, kidney, adrenal glands in rats. Abstracts/Toxicol Lett 196S:S37S351. doi:10.1016/j.toxlet.2010.03.798

26. Aguirre ME, Ruz M, Carrasco F, Rebolledo A, Karla A, Codoceo J, Inostroza J (2007) Effect of moderate energy-restricted diets on the nutritional status of selected minerals in obese women. Arch Latinoam Nutr 57(3):238-247

27. Zafon C, Lecube A, Simo R (2010) Iron in obesity. an ancient micronutrient for a modern disease. Obes Rev 4:322-328

28. Vorugantia VS, Caib G, Klohec DM, Jordan KC, Lane MA, Freeland-Graves JH (2010) Short-term weight loss in overweight/obese low-income women improves plasma zinc and metabolic syndrome risk factors. J Trace Elem Med Biol 24:271-276

29. Konukoglua D, Turhana MS, Ercanb M, Serin O (2004) Relationship between plasma leptin and zinc levels and the effect of insulin and oxidative stress on leptin levels in obese diabetic patients. J Nutr Biochem 15:757-760

30. García-Colunga J, Reyes-Haro D, Godoy-García IU, Miledi R (2005) Zinc modulation of serotonin uptake in the adult rat corpus callosum. J Neurosci Res 80(1):145-149

31. Fujiwara N, Iso H, Kitanaka N, Kitanaka J, Eguchi H, Ookawara T, Ozawa K, Shimoda S, Yoshihara D, Takemura M, Suzuki K (2006) Effects of copper metabolism on neurological functions in Wistar and Wilson's disease model rats. Biochem Biophys Res Commun 349(3):1079-1086

32. Parmar P, Daya S (2001) The effect of copper on (3H)-tryptophan metabolism in organ cultures of rat pineal glands. Metab Brain Dis 16(3-4):199-205

33. Lima SCVC, Arrais RF, Sales CH, Almeida MG, de Sena KCM, Oliveira UTL, de Andrade AS, Pedrosa LFC (2006) Assessment of copper and lipid profile in obese children and adolescents. Biol Trace Elem Res 114:19-26

34. Suliburska J, Bogdanski P, Pupek-Musialik D, Krejpcio Z (2011) Dietary intake and serum and hair concentrations of minerals and their relationship with serum lipids and glucose levels in hypertensive and obese patients with insulin resistance. Biol Trace Elem Biol 139:137-150

35. Naziroglu M (2009) Role of selenium on calcium signaling and oxidative stress-induced molecular pathways in epilepsy. Neurochem Res 34:2181-2191

36. Kovacic P, Somanathan R (2008) Unifying mechanism for eye toxicity: electron transfer, reactive oxygen species, antioxidant benefits, cell signaling and cell membranes. Cell Membr Free Radic Res 2:56-69

37. Naziroglu M, Butterworth PJ (2005) Protective effects of dietary vitamin $\mathrm{C}$ and $\mathrm{E}$ combination on the blood antioxidative defense mechanism in rats with streptozotocin-induced diabetes. Can J Appl Physiol 30:172-185

38. Cimen B (2008) Free radical metabolism in human erythrocytes. Clin Chim Acta 390:1-11

39. Vivoli G, Bergomi M, Rovesti S, Pinotti M, Caselgrandi E (1995) Zinc, copper, and zinc- or copper-dependent enzymes in human hypertension. Biol Trace Elem Res 49(2-3):97-106

40. Pioruńska-Stolzmann M, Iskra M, Majewski W (2001) The activity of cholesterol esterase and ceruloplasmin are inversely related in the serum of men with atherosclerosis obliterans. Med Sci Monit 7(5):940-945

41. Guzman DC, Garcia EH, Mejía GB, Olguín HJ, Jimenez FT, Soto EB, Del Angel DS, Aparicio LC (2012) Effect of sibutramine on 5hydroxyindole acetic acid levels and selected oxidative biomarkers on brain regions of female rats in the presence of zinc. Basic Clin Pharmacol Toxicol 110:421-426. doi:10.1111/j.1742-7843. 2011.00829.x 